\title{
Development of Resistant Gene-Pyramided Japonica Rice for Multiple Biotic Stresses Using Molecular Marker-Assisted Selection
}

\author{
Jung-Pil Suh ${ }^{1}$, Young-Chan Cho ${ }^{1}$, Yong-Jae Won ${ }^{1}$, Eok-Keun Ahn', Man-Kee Baek ${ }^{1}$, Myeong-Ki Kim ${ }^{1}$, \\ Bo-Kyeong Kim', Kshirod K. Jena ${ }^{2} *$ \\ ${ }^{1}$ National Institute of Crop Science, Rural Development Administration, Wanju 55365, Korea \\ ${ }^{2}$ Plant Breeding, Genetics and Biotechnology Division, International Rice Research Institute, DAPO Box 7777, Metro Manila, \\ Philippines
}

\begin{abstract}
Advances in plant molecular techniques have dramatically widened the applicability of gene identification and pyramiding valuable genes. This study was carried out to pyramid five resistance genes for biotic stress into the japonica rice cultivar using marker-assisted selection (MAS) and marker-assisted background analysis of selected progenies using SSR markers. The Pi40, Xa4, xa5, Xa21 and Bph18 genes were combined in Jinbubyeo, a Korean japonica rice variety using MAS. Gene specific co-dominant PCR-based markers were used to select for homozygous recombinant lines in a segregating population derived from a cross between the parental homozygous resistant gene introgression lines. We had successfully developed multiple gene pyramided breeding lines (GPLs) for bacterial blight, blast, and brown planthopper using MAS in rice. The GPLs exhibited high resistance against biotic stress and had around 93\% of the genetic background of the recurrent parent Jinbubyeo based on SSR graphical mapping. The yield and agronomic traits of the GPLs were similar to those of the recurrent parent, indicating that there is no apparent agronomic trait penalty associated with the presence of the resistance genes. The strategy of simultaneous foreground and phenotypic selection to introduce multiple $R$ genes is very useful to reduce the cost and the time required for the isolation of desirable recombinants with target resistance genes in rice. The GPLs could be useful to enhance effective resistance for biotic stress and produce stable grain yield in japonica rice breeding programs.
\end{abstract}

Keywords Rice, Biotic stress, Resistance gene, Pyramiding, Marker assisted selection

\section{INTRODUCTION}

A rapid rise in world population coupled with decreasing agricultural land has exerted pressure on the production and productivity of rice cultivars (Khush 2005). In recent years, modern cultivars have become vulnerable to several biotic stresses like bacterial leaf blight (BB), blast and brown planthopper (BPH), because of the adverse effects of climate change that may be causing changes in disease and insect biotypes. Host-plant resistance is the most effective breeding strategy to control biotic stress in contrast to the environmentally inimical use of pesticides.

Molecular markers can be used to identify and pyramid favorable (or deleterious) and multiple alleles for biotic and abiotic stress resistance in a collection of diverse genotypes (Singh et al. 2001; Lee et al. 2003; Jena and Mackill 2008; Suh et al. 2009). Marker-assisted selection (MAS) for pyramiding important genes along with rapid background recovery of the recurrent parent, while maintaining the exquisite quality characteristics of rice, could be an effective approach for rice improvement (Singh et al. 2001; Sundaram et al. 2008; Xu and Crouch 2008; Suh et al. 2009, 2011; Shanti et al. 2010; Ye 2010). Gene pyramiding is difficult using conventional breeding methods due to the dominance and epistasis effects of genes governing disease resistance. Moreover, genes with similar reactions to two

Received November 7, 2015; Revised November 9, 2015; Accepted November 10, 2015; Published November 30, 2015

*Comesponding author Young-Chan Cho, yccho@korea.kr, Tel: +82-63-238-5211, Fax: +82-63-840-2119

*Comesponding author Kshirod K. Jena, k.jena@irri.org, Tel: +63-2-580-5600, Fax: +63-2-891-1236 
or more races are difficult to identify and transfer through conventional approaches (Joseph et al. 2004; Sundaram et al. 2009; Rajpurohit et al. 2011). However, the availability of molecular markers closely linked with each of the resistance genes makes the identification of plants with two and three genes possible (Singh et al. 2001; Sundaram et al. 2008; Shanti et al. 2010). The effectiveness of MAS breeding depends on the availability of closely linked DNA markers for the target locus, the size of the population, the number of backcrosses, and the position and number of markers for background selection (Frisch and Melchinger 2005). MAS breeding provides a new opportunity for the selective transfer of resistance genes into elite rice cultivars devoid of linkage drag, eventually restoring the recurrent parent genotype (Jairin et al. 2009). In addition, molecular markers precisely estimate the introgression of chromosome segments from donor parents and can speed up the recipient genome recovery via background selection (Neeraja et al. 2007; Jairin et al. 2009; Suh et al. 2009).

Among biotic stresses, bacterial blight (BB), blast and brown planthopper (BPH), are considered serious threats in rice production that cause major diseases. In a previous study, the Pi40 and Bph18 genes were found to have broad-spectrum resistance against multiple rice blast pathogens and BPH biotypes (Suh et al. 2009, 2011). A resistance gene pyramid of $X a 4+x a 5+X a 21$ would be the most effective strategy for improving Korean japonica cultivars for BB resistance (Jeung et al. 2006; Kim et al. 2009; Suh et al. 2013). The Pi40 gene is identified in the introgression line IR65482-4-136-2-2, which inherits the resistance gene from an EE genome wild Oryza species, $O$. australiensis (Acc. 100882). A DNA marker, 9871.T7E2b, was found to be linked to Pi40(t) gene on the short arm of chromosome 6 (Jeung et al. 2007).

In this study, advanced breeding lines derived from BC progenies were used to validate the markers 9871.T7E and 9871.T7E2b as markers completely associated with the Pi40(t) gene. The Bph18 gene has been identified in an indica introgression line, IR65482-7-216-1-2, and it expresses strong resistance to the BPH biotype from Korea. Using gene annotation information from TIGR, a putative resistance gene was identified in the BAC clone OSJNBa0028L05 and sequence information from the putative resistance gene was used to generate the STS marker 7312.T4A linked with the Bph18 gene (Jena et al. 2006). The resistance genes $X a 4+x a 5+X a 21$ were transferred from an indica donor, using a marker-assisted backcrossing breeding strategy, into Jinbubyeo, a BB-susceptible elite japonica rice cultivar that is high yielding with good grain quality (Suh et al. 2013). The DNA markers closely linked with resistance genes for biotic stress also enabled pyramiding of multiple resistance genes using MAS.

This study reports the successful pyramiding of five resistance genes for biotic stresses into japonica rice cultivar using marker-assisted selection (MAS) and marker-assisted background analysis of selected progenies using SSR markers.

\section{MATERIALS AND METHODS}

\section{Plant materials}

Three donors comprised of IRBB57 with a combination of $X a 4+x a 5+X a 21$ genes, IR65482-4-136-2-2 with the Pi40 gene, and IR65482-7-216-1-2 with the Bph18 gene, were used to develop a near-isogeneic line containing the respective genes in the genetic background of Jinbubyeo rice. Jinbubyeo, an elite japonica rice cultivar with early flowering, cold tolerance and good grain quality, was used as the recurrent parent (Table 1). Jinbubyeo-ABL1 was a near isogenic line in the genetic background of Jinbubyeo, possessing three BB resistance genes, Xa4, xa5 and Xa21. Jinbu-ABL2 was a near isogenic line in the genetic background of Jinbubyeo, possessing the Pi40 gene (Suh et al. 2009). Jinbu-ABL3 was a near isogenic line in the genetic background of Jinbubyeo, possessing the Bph18 gene. The three near-isogenic lines in the genetic background of Jinbubyeo consisting of Pi40, Bph18 and a combination of three genes $(X a 4+x a 5+X a 21)$, were used for pyramiding multiple resistant genes (Table 1).

\section{Resistance genes confimation by DNA markers}

Genomic DNA was extracted from the fresh frozen leaves of rice plants using the CTAB method with slight modifications (Murray and Thompson 1980). The presence or absence of five resistance genes (Xa4, xa5, Xa21, Pi40, 
Table 1. List of three advanced backcross breeding lines, gene pyramided lines and parents used in this study.

\begin{tabular}{lll}
\hline \hline Cultivar/breeding line & Description/genes & \multicolumn{1}{c}{ Remarks } \\
\hline Jinbubyeo & Recurrent parent & Korean elite japonica cultivar, cold tolerance \\
IRBB57 & Donor parent & Xa4, xa5 and Xa 21 pyramided line in IR24 \\
IR65482-4-136-2-2 & Donor parent & O. australiensis introgression line with Pi40 gene \\
IR65482-7-216-1-2 & Donor parent & O. australiensis introgression line with Bph18 gene \\
SR30064-2-1-8-20-1-1 & Jinbubyeo-ABL1 & Xa4, xa5 and Xa 21 in Jinbubyeo genetic background \\
SR30062-1-1-9-1-1 & Jinbubyeo-ABL2 & Pi40 in Jinbubyeo genetic background \\
SR30061-6-2-16-1-4 & Jinbubyeo-ABL3 & Bph18 in Jinbubyeo genetic background \\
SR32816(1)-30-2-B & GPL1 & Xa4, xa5, Xa21, Pi40 and Bph18 genes pyramided line \\
SR32816(1)-30-1-B & GPL2 & Xa4, xa5, Xa21, Pi40 and Bph18 genes pyramided line \\
SR32816(1)-22-5-B & GPL3 & $X a 4$, xa5, Xa21, Pi40 and Bph18 genes pyramided line \\
\hline
\end{tabular}

Table 2. Gene-specific polymerase chain reaction primers used for the identification of bacterial blight, blast, BPH resistance genes.

\begin{tabular}{|c|c|c|c|c|c|c|c|c|}
\hline \multirow{2}{*}{$\begin{array}{c}\mathrm{R} \\
\text { genes }\end{array}$} & \multirow{2}{*}{$\begin{array}{l}\text { Chr. } \\
\text { No }\end{array}$} & \multirow{2}{*}{ Markername } & \multicolumn{2}{|c|}{ Primer sequences used for gene detection } & \multirow{2}{*}{$\begin{array}{c}\text { Exp. } \\
\text { Size (bp) }\end{array}$} & \multirow{2}{*}{ Enzyme } & \multirow{2}{*}{ Bandtype } & \multirow{2}{*}{ Reference } \\
\hline & & & Forward (5'-3') & Reverse (5'-3') & & & & \\
\hline Xa4 & 11 & MP1+MP2 & ATC GAT CGA TCT TCA CGA GG & TGC TAT AAA AGG CAT TCG G & 150 & None & Codominant & Sun et al. 2003 \\
\hline$x a 5$ & 5 & 10603.T10Dw & GCA CTG CAA CCA TCA ATG AATC & CCT AGG AGA AAC TAG CCG TCC A & 280 & Rsa I & Codominant & Suh et al. 2013 \\
\hline Xa21 & 11 & $\mathrm{U} 1+\mathrm{I} 1$ & CGA TCG GTA TAA CAG CAA AAC & ATA GCA ACT GAT TGC TTG G & 1,400 & None & Codominant & Wang et al. 1996 \\
\hline Pi40 & 6 & 9871.T7E2b & CAA CAA ACG GGT CGA CAA AGG & CCC CCA GGT CGT GAT ACC TTC & 642 & Tsp 509I & Codominant & Jeung et al. 2007 \\
\hline Bph18 & 12 & 7312.T4A & ACG GCG GTG AGC ATT GG & TAC AGC GAA AAG CAT AAA GAG TC & 1,078 & Hinf I & Codominant & Jena et al. 2006 \\
\hline
\end{tabular}

Bph18) was validated using foreground selection with gene-specific DNA markers in the parents and in the breeding lines (Table 2). Three gene-specific PCR markers, MP1+MP2, 10603.T10Dw and U1/I1 were used to confirm the presence of the three BB resistance genes $X a 4, x a 5$ and Xa21, respectively. Two SCAR markers, 9871.T7E2b and 7312.T4A were used to detect the presence of the Pi40 and Bph18 genes, respectively (Jena et al. 2006; Jeung et al. 2007). Polymerase chain reaction (PCR) was performed in a Bio-Rad PTC-200 Thermocycler, Germany, with a total volume of $20 \mu \mathrm{l}$ containing $20 \mathrm{ng}$ of template DNA, 5 pmole of each primer, $1.5 \mathrm{mM}$ of $\mathrm{MgCl}_{2}, 0.2 \mathrm{mM}$ of dNTP and $0.5 \mathrm{U}$ of Taq polymerase. PCR amplification, restriction digestion and gel staining were conducted following the procedure described by Suh et al. (2009, 2011, 2013).

\section{Bacterial blight inoculation and evaluation}

The parents and breeding lines of the $\mathrm{F}_{6}$ generation were grown in the greenhouse of the National Institute of Crop Science (NICS), RDA in Suwon. At the maximum tillering stage, the leaves of two plants from each plot were inoculated with four races: K1, K2, K3, and K3a of Xanthomonas oryzae pv. oryzae (Xoo) isolates using the leaf clipping method with a bacterial suspension of $10^{9}$ cells $/ \mathrm{ml}$. The lesion lengths $(\mathrm{cm})$ for the 12 inoculated leaves (six leaves from two plants per plot) were measured 14 days after inoculation. The resistance was expressed by the lesion length (resistant: $<3 \mathrm{~cm}$, moderately resistant: $3-5 \mathrm{~cm}$, susceptible: $>5 \mathrm{~cm}$ ) (Jeung et al. 2006).

\section{Evaluation of blast resistance}

Three-week-old seedlings of parents and $\mathrm{F}_{6}$ breeding lines were inoculated with blast isolate suspension as described by Kim et al. (2004). The fungal spore suspension concentration was adjusted to $1.5 \times 10^{5} \mathrm{spores} / \mathrm{ml}$. For screening against 29 individual isolates of $M$. grisea, seedlings were spray inoculated with $20 \mathrm{ml}$ of spore suspension using an electric motor sprayer to ensure an even and uniform distribution of spores. The inoculated seedlings were kept for $24 \mathrm{~h}$ in a dew growth chamber at $26 \pm 1^{\circ} \mathrm{C}$ and then transferred to the greenhouse with a 12/12 h (day/night) photoperiod at $90 \%$ relative humidity for 7 days. SPM (sequential planting method) to confirm the durability to blast resistance was conducted using a mixture of 29 representative isolates of 22 predominant blast races in Korea (Kim et al. 2004). All inoculations and disease 
evaluations were conducted in the greenhouse of the NICS, RDA in Suwon. The test materials were also planted in rice blast nurseries at 12 hot-spot regions. The blast nursery test was conducted following the standard evaluation method from IRRI (IRRI 1996).

\section{Evaluation of BPH resistance}

A BPH bioassay was performed using the modified bulk seedling test in the greenhouse following the method described by Jena et al. (2006). Twelve seeds of $\mathrm{F}_{6}$ breeding lines along with resistant $(R)$ and susceptible $(S)$ checks were planted in randomly selected rows in seed boxes, and seedlings at the three-leaf stage were infested with 2nd- or 3rd-instar nymphs at a density of 10-12 nymphs per seedling. The breeding lines were rated as resistant or susceptible once the susceptible check was dead.

\section{Background profiling by SSR marker analysis}

A total of 260 SSR markers of known chromosomal positions distributed evenly on the 12 chromosomes with an average marker interval of $5.9 \mathrm{cM}$ was used in a genome-wide survey to identify the chromosome segment substitution locations in the selected $F_{6}$ breeding lines compared with the donor line. The polymorphic SSR markers between the two parents were used for graphical mapping to recover the recipient parent genome. The lengths of substituted chromosome segments in ABL were estimated based on the graphical genotyping procedure (Xi et al. 2006; Suh et al. 2009). A chromosome segment flanked by homozygous marker alleles of the donor parent was considered a $100 \%$ donor type, a chromosome segment flanked by homozygous marker alleles of the recipient parent was considered a $0 \%$ donor type and a chromosome segment flanked by one marker allele of the donor parent and another marker allele of the recipient parent was considered a 50\% donor type. The linkage and orientation of SSR markers on chromosomes were assigned following the SSR map constructed by McCouch et al. (2002) and as depicted in Gramene (www.gramene.org/).

\section{Evaluation of agronomic traits and grain quality}

The parents and the breeding lines were planted in a four-row plot with 35 plants per row by $30 \times 15 \mathrm{~cm}$ spacing in a randomized complete block design with three replications. The plants were evaluated for agronomic traits in the rice experimental plot of NICS, Suwon, Korea, using the standard evaluation method for rice (RDA 2003). The amount of standard fertilizer application in the experiment field was $\mathrm{N}-\mathrm{P}_{2} \mathrm{O}_{5}-\mathrm{K}_{2} \mathrm{O}=9-4.5-5.7 \mathrm{~kg} / 10 \mathrm{a}$. Commercial pesticides were applied to the rice plant materials. For each line, five plants in the middle rows were used to determine days to heading (DTH), culm length (CL), panicle number (PN), panicle length (PL), number of grains per panicle (NGP), fertility of spikelets (FER), 1,000-grain weight of the brown rice (GW), and ratio of the seed length/width (L/W). The fertility of the spikelets was calculated as the ratio of fertile spikelets to the total number of spikelets. Grain yield (t/ha) per plot was evaluated based on a grain harvest of 100 plants in the central row of each plot. Grain quality was estimated for the alkali digestion value (ADV), amylose content of milled rice (AC), protein content of brown rice (PC) and chalkiness of brown rice (CK; 0: non-chalkiness, 3: high chalkiness). ADV was evaluated based on the procedure described by Little et al. (Little et al. 1998). AC was determined by the relative absorbency of starch-iodine color in a digested solution of 100-mesh rice flour using Juliano's (Juliano 1971) modified method. PC was calculated as total nitrogen multiplied by 5.95 after determining the nitrogen content of the rice material using the Micro-Kjeldahl method (Foss: 2300 Kjeltec Analyzer). The least significant difference (LSD) and Duncan's multiple range test (DMRT) were used for multiple mean comparisons using the SAS statistical software package (version 8.2; SAS Institute, Cary, NC).

\section{RESULTS}

Development of advanced backcross breeding lines (ABL) with resistance gene(s)

Jinbubyeo-ABLs were developed by the marker-assisted backcross (MAB) breeding strategy (Fig. 1). The MAB breeding strategy followed the procedure employed by Suh et al. 2009, 2011, 2013. A cross was made between Jinbubyeo and IRBB57, IR65482-4-136-2-2, IR65482-7- 


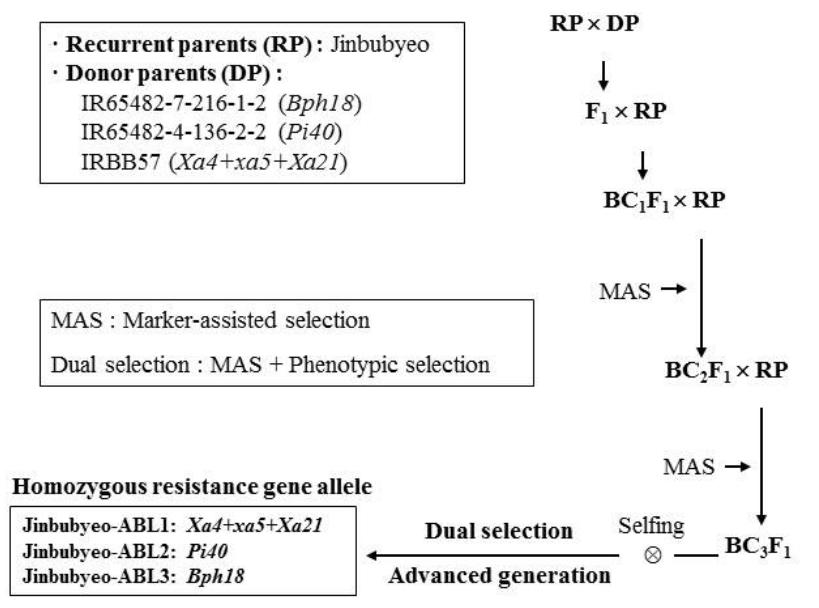

Fig. 1. Scheme diagram for the development of advanced backcross breeding lines (ABL) with resistance to bacterial blight, blast and brown planthopper through MAS.

216-1-2 which carries Xa4+xa5+Xa21, Pi40 and Bph18 genes. $F_{1}$ plants were backcrossed with the recurrent parent Jinbubyeo. Among the $\mathrm{BC}_{1-3} \mathrm{~F}_{1}$ plants, PCR-based molecular markers linked to the target genes were used to select plants with resistance alleles. The $\mathrm{BC}_{3} \mathrm{~F}_{2}$ plants were self-pollinated and advanced generation progenies were produced on the basis of marker-assisted selection (MAS). The Jinbubyeo$\mathrm{ABLs}$ from $\mathrm{BC}_{3} \mathrm{~F}_{5}$ plants were selected based on their reaction to $\mathrm{BB}$, blast, $\mathrm{BPH}$ and the presence of homozygous marker alleles for the target resistance genes. Finally, three Jinbubyeo-ABLs were developed with $X a 4+x a 5+X a 21$, Pi40, Bph18 genes (Table 1, Fig.1).

\section{Multiple resistance genes pyramided lines (GPLs) against BB, blast, BPH by MAS}

The three Jinbubyeo-ABLs with one or three resistance genes were used as the donor parents for pyramiding resistance genes. The five genes pyramided lines (GPLs) were developed based on phenotypic selection and MAS procedure applied to the foreground selection using the target gene-specific DNA markers (Fig. 2). Two types of $\mathrm{F}_{1}$ plants were obtained from the two cross combinations of Jinbubyeo-ABL1/Jinbubyeo-ABL2 and Jinbubyeo-ABL1/ Jinbubyeo-ABL3. These two $F_{1}$ plants were crossed with each other to pyramid the five resistance genes. $86 \mathrm{~F}_{1}$ plants were obtained from the double cross (Fig. 2). Of the $86 \mathrm{~F}_{1}$

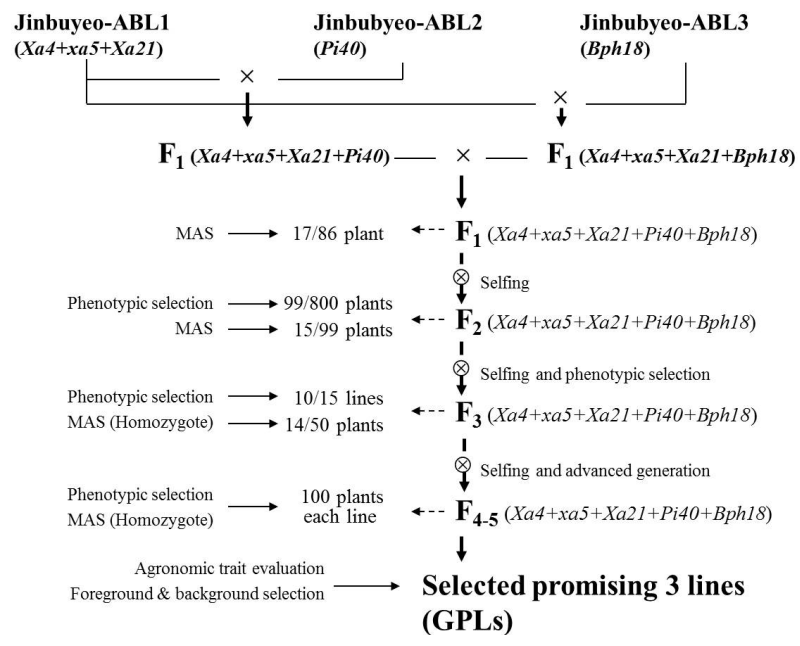

Fig. 2. Scheme diagram for pyramiding five $R$ genes to bacterial blight, blast and brown planthopper based on foreground selection and MAS.

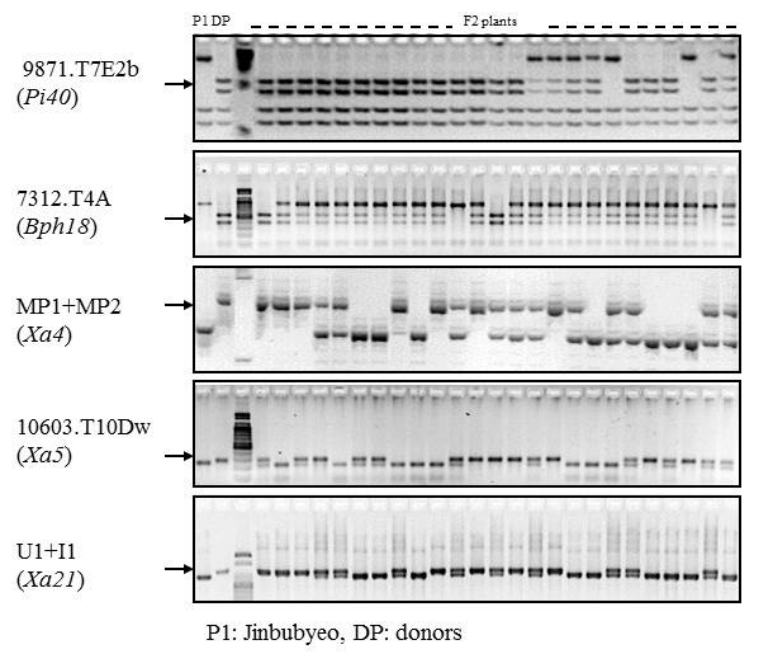

Fig. 3. PCR analysis of the parental lines and $F_{2}$ plants and resistance gene confirmation by MAS for primers 9871.T7E2b (Hinf I and Tsp509 I-digestion for Pi40, 7312.T4A (Hinf I-digestion) for Bph18 and MP1+MP2, 10603.T10Dw (Rsa I-digestion) and U1/I1 linked with resistance genes Xa4, xa5 and Xa21, respectively. P1: Jinbubyeo, DP: Each donor parent for the target biotic stress in Table 1.

plants that were analyzed with five gene-specific DNA markers, $17 \mathrm{~F}_{1}$ plants were selected as having the allele of the target resistance genes. $800 \mathrm{~F}_{2}$ plants from the selected $\mathrm{F}_{1}$ plants were transplanted in the experimental plot. $99 \mathrm{~F}_{2}$ plants were selected by phenotypic selection. Of the $99 \mathrm{~F}_{2}$ 
plants, 15 plants were selected as having an allele of the five resistance genes on the basis of molecular marker analysis (Fig. 3). The selected $15 \mathrm{~F}_{2}$ plants were harvested as seeds and transplanted as $F_{3}$ breeding lines by the pedigree method. 10 out of 15 breeding lines were selected by the phenotype and $14 \mathrm{~F}_{3}$ plants were selected in the 10 breeding lines by MAS. Progenies of the $\mathrm{F}_{3}$ plants were advanced to the $F_{6}$ generation by self-pollination and phenotypic selection. Phenotypic selection at each selfpollination generation was conducted to eliminate plants with linkage drag such as sterility, tallness, and late flowering, among others. Thus, the population size for MAS was reduced to remove undesirable phenotypic plants. Finally, three GPLs (gene pyramided lines) were selected as promising lines having $\mathrm{BB}$, blast, and $\mathrm{BPH}$ resistance with homozygous marker alleles of the $X a 4+x a 5+X a 21$, Pi40 and Bph18 genes (Fig. 2, Fig. 4).

\section{Resistance against BB, blast, BPH bioassay}

The three GPLs with five resistance genes were evaluated for their resistance under glasshouse conditions with the four predominant races $\mathrm{K} 1, \mathrm{~K} 2, \mathrm{~K} 3$, and K3a of Xoo from Korea. The GPLs were highly resistant against all isolates of Xoo, with average lesion length $<0.3 \mathrm{~cm}$ (Table 3, Fig. 5). Jinbubyeo was highly susceptible to all isolates, with lesion length ranging from 10 to $14.7 \mathrm{~cm}$. The three GPLs were compatible with only two of 29 isolates of $M$. grisea, whereas Jinbubyeo showed compatibility with 7 isolates of M. grisea (Table 3). SPM (sequential planting method) was conducted to confirm the durable resistance of the GPLs against blast (Suh et al. 2009). The GPLs also showed strong resistance in sequential plantings using the mixed M. grisea with 29 blast isolates predominant in Korea (Table 3). The GPLs showed 0-3\% DLA (diseased leaf area) during 7 sequential plantings. Therefore,

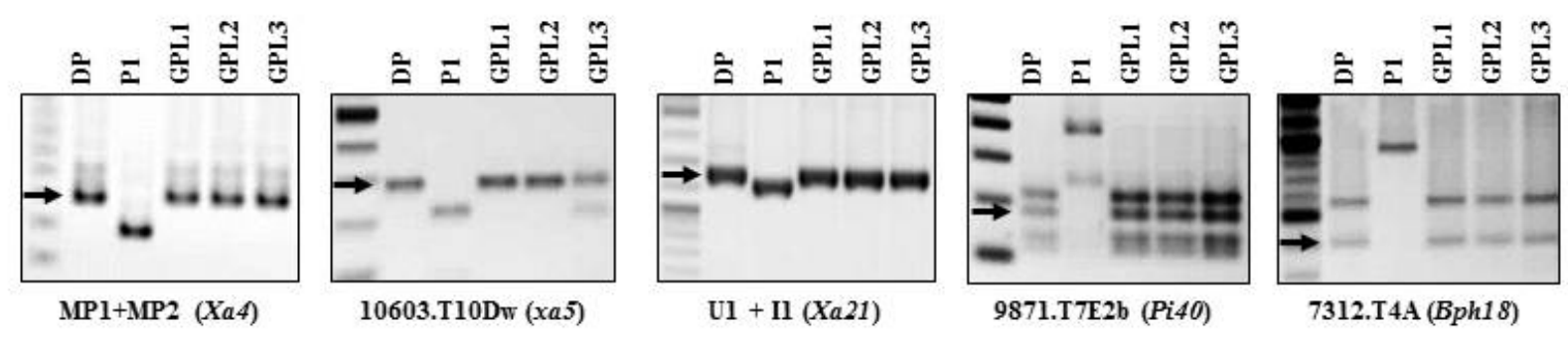

Fig. 4. PCR analysis for $R$ gene-confirmation in three GPLs pyramided with five $R$ genes to bacterial blight, blast and brown planthopper using five DNA markers of MP1+MP2, 10603.T10Dw (Rsa I-digestion) and U1/I1 linked with resistance genes Xa4, xa5 and Xa21, respectively, 9871.T7E2b (Hinf I and Tsp509 I-digestion for Pi40, and 7312.T4A (Hinf I-digestion) for Bph18. DP: Each donor parent for the target biotic stress in Table 1, P1: Jinbubyeo. GPL: 5 genes pyramided lines.

Table 3. Reaction patterns of selected GPLs to three biotic stresses.

\begin{tabular}{|c|c|c|c|c|c|c|c|c|}
\hline \multirow{3}{*}{ Cultivar } & \multicolumn{3}{|c|}{ Blast resistance } & \multicolumn{4}{|c|}{ "Bacterial blight resistance ${ }^{\mathrm{z})}$} & \multirow{3}{*}{$\begin{array}{c}\text { Brown } \\
\text { planthoppe } \\
\text { resistance }\end{array}$} \\
\hline & \multirow[b]{2}{*}{ Blast nursery } & \multicolumn{2}{|c|}{ Sequential planting method ${ }^{\mathrm{y})}$} & \multirow[b]{2}{*}{ K1 } & \multirow[b]{2}{*}{ K2 } & \multirow[b]{2}{*}{ K3 } & \multirow[b]{2}{*}{ КЗа } & \\
\hline & & $\begin{array}{c}\text { No. of } \\
\text { compatibleisolates }\end{array}$ & $\begin{array}{l}\text { Durability } \\
\text { (1-7) }\end{array}$ & & & & & \\
\hline Jinbubyeo & MR & 7 & 7 & $\mathrm{~S}$ & $\mathrm{~S}$ & S & S & S \\
\hline GPL1 & $\mathrm{R}$ & 2 & 1 & $\mathrm{R}$ & $\mathrm{R}$ & $\mathrm{R}$ & $\mathrm{R}$ & $\mathrm{R}$ \\
\hline GPL2 & $\mathrm{R}$ & 2 & 1 & $\mathrm{R}$ & $\mathrm{R}$ & $\mathrm{R}$ & $\mathrm{R}$ & $\mathrm{R}$ \\
\hline GPL3 & $\mathrm{R}$ & 2 & 1 & $\mathrm{R}$ & $\mathrm{R}$ & $\mathrm{R}$ & $\mathrm{R}$ & $\mathrm{R}$ \\
\hline
\end{tabular}

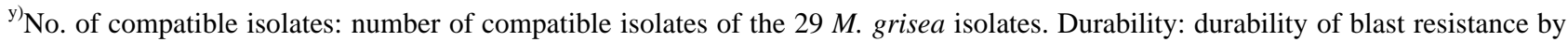
sequential planting method: 1 (durability)-7 (non-durability).

${ }^{\mathrm{z})} \mathrm{K} 1, \mathrm{~K} 2, \mathrm{~K} 3$, K3a: races of Korean BB isolates.

$\mathrm{R}$ : resistance, MR: moderately resistance, S: susceptible. 
A) $\mathrm{BB}$ resistance

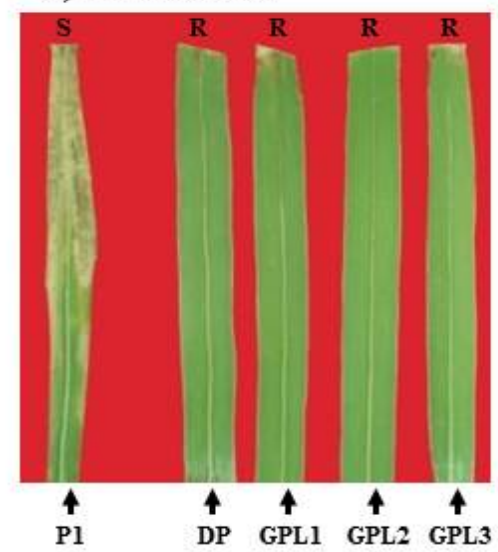

B) Blast resistance

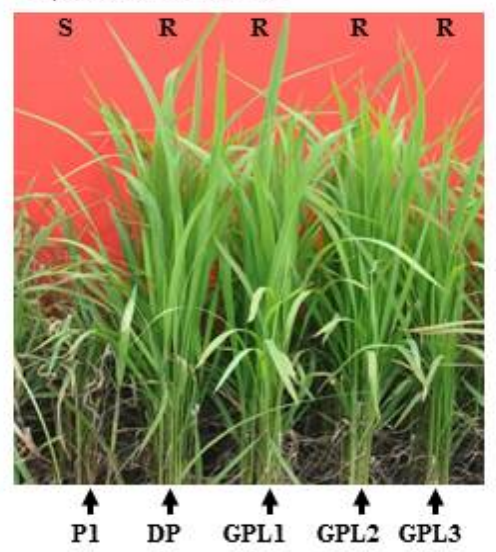

\section{C) $\mathrm{BPH}$ resistance}

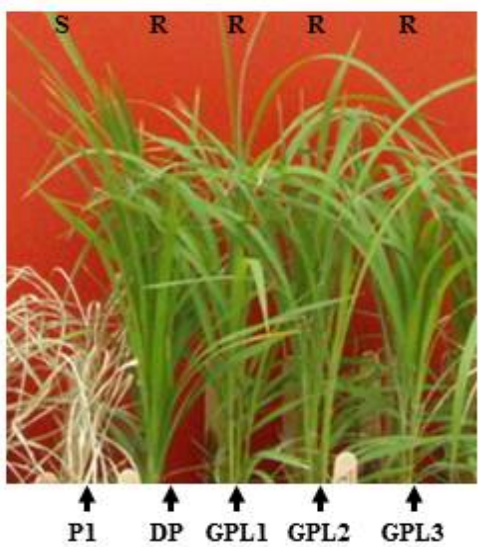

Fig. 5. The levels of resistance to bacterial blight, blast, and brown planthopper of recurrent parent, each donor for each biotic stress (in Table 1), and the three GPLs pyramided with five $R$ genes. P1: Jinbubyeo, DP: donor, GPL: 5 genes pyramided lines, S: susceptible, R: resistance.

Chr. 1

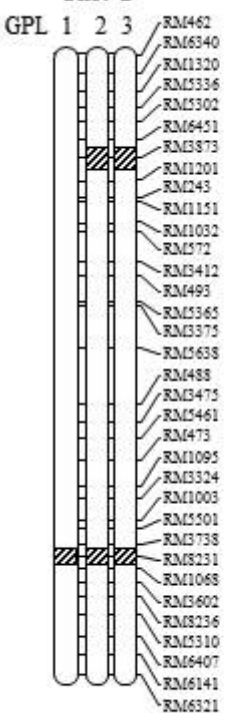

Chr. 7
Chr. 2

GPL $1223 /$ RM:

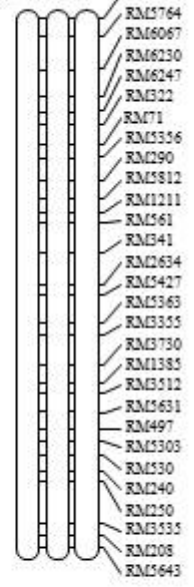

Chr. 8

GPL 12

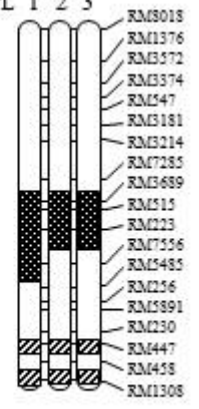

Chr. 3

GPI 12

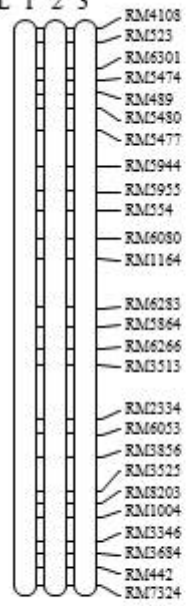

Chr. 9

GPL $122 \quad 3$

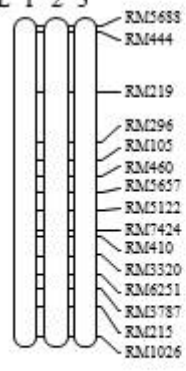

Chr. 4

GPL 123

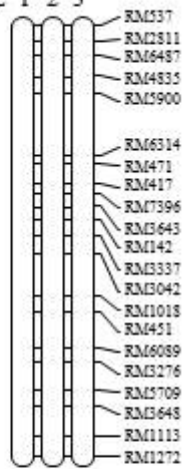

Chr. 5

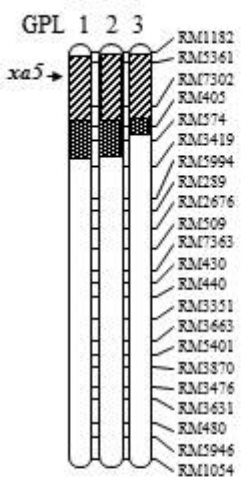

Chr. 6

GPL 12

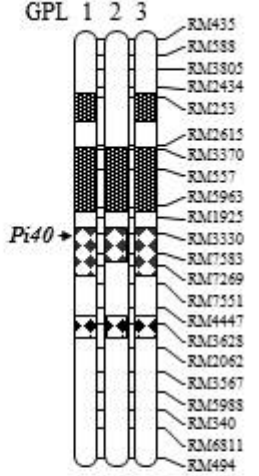

Region of IRBB57 (Donor of Xa4+xa5+Xa2l)

Region of IR65482-4-136-2-2 (Donor of Pi40)

臣 Region of IR65482-7-216-1-2 (Donor of Bph18)

Common region with IRBB57, IR65482-4-136-2-2, IR65482-7-216-1-2 Region of Jinbubyeo

Chr. 10

GPL 122

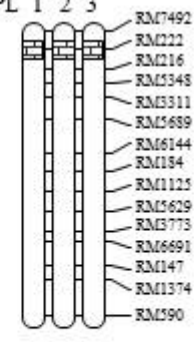

Chr. 11

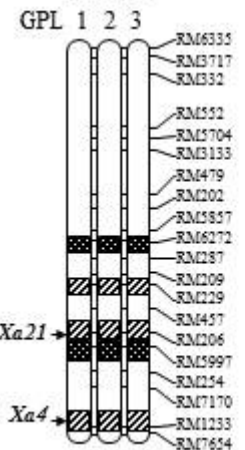

Chr. 12

GPL 125

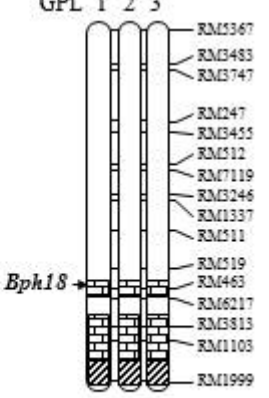

Fig. 6. Background selection of three gene-pyramided lines (GPL) in Jinbubyeo genetic background. Letters A, B and C on top are GPL1, GPL2 and GPL3, respectively. The black box indicates substituted chromosome segments of the donor parent in the GPLs. 
considering 40\% DLA as the disease threshold index, the GPLs exhibited durable resistance to Korean $M$. grisea isolates. Jinbubyeo demonstrated a moderate level of blast resistance. The three GPLs also expressed complete resistance in blast nursery tests for 12 regions in Korea over two years, whereas Jinbubyeo showed only a moderate level of resistance in the same blast nurseries (Table 3, Fig. 5). BPH bioassays of Jinbubyeo and the three GPLs at the seedling stages were evaluated. The three GPLs showed strong BPH resistance, while Jinbubyeo expressed high susceptibility to BPH (Table 3, Fig. 5).

\section{SSR-based genetic background profiling of GPL}

A total of 260 SSR markers were used for background selection of the three GPLs along with the donor lines and a genetic map covering a 1,512.4 cM region of the $O$. sativa genome was constructed (Fig. 6). Each GPL contained an SSR marker-defined chromosome segment from the donor in the genetic background of the recurrent parent, Jinbubyeo. The average percentage of donor parent chromosome substitution in GPL1, GPL2 and GPL3 was 14.2, 12.6 and 14.2\%, respectively (Table 4, Fig. 6). The substituted chromosome segments in GPLs were mainly distributed around the regions of target resistance genes on chromo- somes 5, 6, 11 and 12. However, some chromosome segments of donors were exhibited on chromosomes 1, 7, 8 and 10 ranging from 5.1 to $24.2 \%$. Chromosomes 2, 3, 4, and 9 were completely converted to the Jinbubyeo parent genotype with no introgressed segments from the donors (Fig. 6).

\section{Evaluation of agronomic traits and grain quality of GPLs}

The major agronomic traits for the plant type and the physico-chemical traits related to grain quality for the three GPLs were evaluated in the field and laboratory (Table 5). Traits such as culm length, panicle number, 1,000-grain weight of brown rice, and grain yield were similar to those of the recurrent parent Jinbubyeo. The physico-chemical traits, amylose content (AC) and alkali digestion value (ADV) of milled rice, as well as the protein content (PC) of brown rice were almost the same as those of Jinbubyeo. However, the DTH of the GPLs were 5-6 days longer than those of Jinbubyeo and the panicle length of the three GPLs was 1-2 cm longer. The number of spikelets per panicle and the seed fertility of the GPLs were more than and lower than those of Jinbubyeo, respectively. The grain yields of the GPLs did not show a significant difference from Jinbubyeo but GPL1 had slightly better yield than

Table 4. Substituted chromosome segments from donor parent in gene pyramided lines by SSR marker analysis.

\begin{tabular}{|c|c|c|c|c|c|c|c|c|c|}
\hline \multirow{2}{*}{$\begin{array}{l}\text { Chr. } \\
\text { no. }\end{array}$} & \multirow{2}{*}{$\begin{array}{l}\text { No. of } \\
\text { markers }\end{array}$} & \multirow{2}{*}{$\begin{array}{c}\text { Chr. } \\
\text { length }(\mathrm{cM})^{\mathrm{w})}\end{array}$} & \multirow{2}{*}{$\begin{array}{l}\text { Interval } \\
(\mathrm{cM})^{\mathrm{x})}\end{array}$} & \multicolumn{3}{|c|}{ Chromosome segments of donor $(\mathrm{cM})^{\mathrm{y})}$} & \multicolumn{3}{|c|}{ Chromosome segments of donor $(\%)^{\mathrm{z})}$} \\
\hline & & & & GPL1 & GPL2 & GPL3 & GPL1 & GPL2 & GPL3 \\
\hline 1 & 34 & 181.8 & 5.3 & 3.5 & 9.3 & 9.3 & 1.9 & 5.1 & 5.1 \\
\hline 2 & 29 & 157.9 & 5.4 & 0.0 & 0.0 & 0.0 & 0.0 & 0.0 & 0.0 \\
\hline 3 & 26 & 164.4 & 6.3 & 0.0 & 0.0 & 0.0 & 0.0 & 0.0 & 0.0 \\
\hline 4 & 21 & 129.6 & 6.2 & 0.0 & 0.0 & 0.0 & 0.0 & 0.0 & 0.0 \\
\hline 5 & 22 & 122.0 & 5.5 & 29.8 & 29.8 & 24.1 & 24.4 & 24.4 & 19.7 \\
\hline 6 & 22 & 124.4 & 5.7 & 54.1 & 38.8 & 54.1 & 43.5 & 31.2 & 43.5 \\
\hline 7 & 21 & 118.3 & 5.6 & 15.3 & 11.5 & 24.8 & 12.9 & 9.7 & 20.9 \\
\hline 8 & 19 & 119.9 & 6.3 & 37.2 & 28.9 & 28.9 & 31.0 & 24.1 & 24.1 \\
\hline 9 & 15 & 92.1 & 6.1 & 0.0 & 0.0 & 0.0 & 0.0 & 0.0 & 0.0 \\
\hline 10 & 15 & 83.8 & 5.6 & 5.9 & 5.9 & 5.9 & 7.0 & 7.0 & 7.0 \\
\hline 11 & 20 & 115.1 & 5.8 & 29.7 & 29.7 & 29.7 & 25.8 & 25.8 & 25.8 \\
\hline 12 & 16 & 103.1 & 6.4 & 25.1 & 25.1 & 25.1 & 24.3 & 24.3 & 24.3 \\
\hline Total & 260 & $1,512.4$ & 5.9 & 200.4 & 178.8 & 201.7 & 14.2 & 12.6 & 14.2 \\
\hline
\end{tabular}

${ }^{\text {v) }}$ Chromosome number.

${ }^{\text {w) }}$ Chromosome length in centiMorgan (cM).

${ }^{\mathrm{x})}$ Average marker interval.

${ }^{\mathrm{y})}$ Introgressed chromosome segment length (cM) of donor parent in Jinbu genetic background.

${ }^{\mathrm{z})}$ Percentage (\%) of introgressed chromosome segment of donor parent in Jinbu genetic background. 
Table 5. Performance of principal agronomic traits and grain quality of three GPLs.

\begin{tabular}{|c|c|c|c|c|c|c|c|c|c|c|c|c|c|}
\hline \multirow{2}{*}{$\begin{array}{c}\text { Cultivar/ } \\
\text { breeding } \\
\text { line }\end{array}$} & \multicolumn{9}{|c|}{ Agronomic traits $^{\mathrm{y})}$} & \multicolumn{4}{|c|}{ Traits related to grain quality ${ }^{\mathrm{z})}$} \\
\hline & $\begin{array}{c}\text { DTH } \\
\text { (date) }\end{array}$ & $\begin{array}{c}\mathrm{CL} \\
(\mathrm{cm})\end{array}$ & $\begin{array}{c}\text { PL } \\
(\mathrm{cm})\end{array}$ & $\mathrm{PN}$ & NGP & $\begin{array}{c}\text { FER } \\
(\%)\end{array}$ & $\begin{array}{c}\text { GY } \\
\text { (t/ha) }\end{array}$ & $\begin{array}{c}\text { GW } \\
\text { (g) }\end{array}$ & $\begin{array}{l}\mathrm{L} / \mathrm{W} \\
(\mathrm{cm})\end{array}$ & CK & $\begin{array}{l}\mathrm{AC} \\
(\%)\end{array}$ & $\begin{array}{l}\text { PC } \\
(\%)\end{array}$ & $\begin{array}{l}\text { ADV } \\
(1-7)\end{array}$ \\
\hline Jinbubyeo & $7.20^{\mathrm{a}}$ & $74^{\mathrm{a}}$ & 18 & 14 & $67^{\mathrm{b}}$ & $92.3^{\mathrm{a}}$ & $678^{\mathrm{b}}$ & $25.4^{\mathrm{a}}$ & 1.79 & $0 / 1$ & 18.5 & 7.9 & 6.3 \\
\hline GPL1 & $7.25^{\mathrm{a}}$ & $75^{\mathrm{a}}$ & 19 & 15 & $90^{\mathrm{a}}$ & $80.2^{\mathrm{b}}$ & $741^{\mathrm{a}}$ & $24.8^{\mathrm{a}}$ & 1.69 & $0 / 2$ & 18.9 & 6.8 & 6.4 \\
\hline GPL2 & $7.26^{\mathrm{a}}$ & $76^{\mathrm{a}}$ & 19 & 14 & $89^{a}$ & $75.3^{b}$ & $659^{\mathrm{b}}$ & $24.5^{\mathrm{a}}$ & 1.80 & $0 / 2$ & 18.7 & 6.5 & 6.5 \\
\hline GPL3 & $7.26^{\mathrm{a}}$ & $75^{\mathrm{a}}$ & 20 & 15 & $84^{\mathrm{a}}$ & $76.5^{\mathrm{b}}$ & $667^{\mathrm{b}}$ & $25.2^{\mathrm{a}}$ & 1.70 & $1 / 2$ & 18.5 & 6.7 & 6.5 \\
\hline
\end{tabular}

${ }^{\mathrm{y})}$ DTH: days to heading, CL: culm length $(\mathrm{cm})$, PL: panicle length $(\mathrm{cm})$, PN: panicle number, NGP: number of grains per panicle, FER: fertility of spikelets (\%), GY: grain yield (t/ha), GW: 1,000-grain weight of brown rice (g), L/W: ratio of seed length/width.

${ }^{\mathrm{Z})} \mathrm{CK}$ : chalkiness, AC: amylose content (\%), PC: protein content (\%), ADV: alkali digestive value.

a,b: Means followed by the same letter are not significant at the $5 \%$ significance level by the least significant difference test (LSD=0.05).

Jinbubyeo. The characteristics related to grain quality such as AC, PC, ADV for the three GPLs were similar to the japonica recurrent parent Jinbubyeo (Table 5). However, the weaknesses of the GPLs were not clear, with 0/2-1/2 in the chalkiness of the endosperm compared to $0 / 1$ of the recurrent parent Jinbubyeo. Two lines, GPL2 and GPL3, showed degeneration at the tip of the panicle. Altogether, GPL1 showed the most favorable agronomic traits that were similar to Jinbubyeo including grain yield.

\section{DISCUSSION}

The most devastating diseases and insect pest are blast, bacterial blight and brown planthopper in the rice growing regions of Korea as well as throughout Asia. Many japonica cultivars have been developed in Korea with resistance to blast, caused by $M$. oryzae. Most Korean japonica varieties contain a few $R$ genes to blast (Cho et al. 2007). However, the resistance in most cultivars broke down within a few years after they were released to farmers because of the spread of new races of $M$. grisea, which became virulent to the resistant cultivars (Lee and Cho 1990; Han et al. 2001). Hence, there is a need to identify broad-spectrum $R$ gene(s) to blast for the purpose of enhancing durability and preventing resistance break-down. Also, a new bacterial blight (BB) race, K3a, caused by Xanthomonas oryzae pv. oryzae (Xoo) that evolved recently caused serious damage to rice production in the southwestern coastal areas of Korea in 2003 (Noh et al. 2003). BB disease is spreading to all regions of Korea because of the effect of climate change and is causing genetic vulnerability in modern cultivars. As a result, rice yield has declined and grain quality has decreased with infections of BB (Noh et al. 2007). In recent years, modern cultivars have become vulnerable to brown planthopper (BPH) because of changes in BPH biotypes. BPH (Nilaparvata lugens Stal.) is one of the most destructive phloemsapfeeding insect pests of rice. It damages rice crops every year and the most serious cases of BPH infestations cause hopper burn in rice fields and eventually cause complete yield loss in many Asian countries (Jena et al. 2006).

The breeding and development of resistant cultivars carrying major resistance $(R)$ genes have been the most effective and economical strategy to control blast, $\mathrm{BB}$, and $\mathrm{BPH}$ whilst maintaining a neutral effect on the environment (Singh et al. 2001; Jena and Mackill 2008). Qualitative resistance, which confers major gene-specific resistance against some pathogen races and insect pests, is the easiest to incorporate into breeding programs. However, for many pathogens and insects, this type of qualitative resistance is not often durable because of rapid changes in the virulence of the pathogen or the biotype of the population (Leach et al. 2007). As a result, research to increase durability has focused on the accumulation of major disease resistance genes in crop plants. In this study, we selected a few $R$ genes: Pi40 to blast, Xa4, $x a 5$ and Xa21 to $\mathrm{BB}$, and $B p h 18$ to $\mathrm{BPH}$ for pyramiding. A single $R$ gene, $P i 40$, originating from an EE genome wild Oryza species, O. australiensis (Acc. 100882), showed stable resistance to broad-spectrum isolates to blast (Jeung et al. 2007; Suh et $a l$ 2007). Pyramiding the resistance genes $\mathrm{Xa4}, \mathrm{xa} 5$ and 
Xa21 provided the most effective strategy for improving Korean japonica cultivars for BB resistance (Jeung et al. 2006; Kim et al. 2009). Additionally, the combination of two dominant and one recessive BB resistance genes did not have any negative effects on agronomic traits in the ABL. The Bph18 gene, originating from an indica introgression line, expresses strong resistance to the $\mathrm{BPH}$ biotype (Jena et al. 2006; Suh et al. 2011). BPH resistant elite breeding lines of Bph18 with agronomic and grain quality traits similar to those of the recurrent parent were successfully developed by foreground and background analysis in a japonica background without linkage drag (Suh et al. 2011).

Molecular markers can be used to identify and pyramid favorable (or deleterious) and multiple alleles for biotic and abiotic stress resistance in a collection of diverse genotypes (Singh et al. 2001; Lee et al. 2003; Jena and Mackill 2008). Marker-assisted selection (MAS) for pyramiding important genes along with rapid genetic background recovery of the recurrent parent, while maintaining the exquisite quality characteristics of rice, could be an effective approach for rice improvement (Singh et al. 2001; Sundaram et al. 2008; Xu and Crouch 2008; Shanti et al. 2010; Ye 2010; Suh et al. 2011). Gene pyramiding is difficult using conventional breeding methods due to the dominance and epistasis effects of genes governing disease and insect resistance. However, the availability of molecular markers closely linked to each of the resistance genes makes the identification of plants with several $R$ genes possible (Singh et al. 2001; Sundaram et al. 2008; Shanti et al. 2010). Nevertheless, it is possible to transfer or pyramid valuable $R$ genes of blast (Suh et al. 2009; Divya et al. 2014; Lee et al. 2015), BB (Singh et al. 2001; Joseph et al. 2004; Sundaram et al. 2008; Rajpurohit et al. 2011; Suh et al. 2013; Park et al. 2014; Pradhan et al. 2015), and BPH (Jairin et al. 2009; Fujita et al. 2010; Suh et al. 2011) based on marker-assisted selection.

A recurrent parent, Jinbubyeo was crossed with three donors: IRBB57 possessing a combination of Xa4+xa5+Xa21 genes, IR65482-4-136-2-2 possessing the $P i 40$ gene, and IR65482-7-216-1-2 possessing the Bph18 gene, for the purpose of pyramiding the five $R$ genes (Fig. 1). The $F_{1}$ plants selected through MAS for target $R$ genes were backcrossed to the recurrent parent, Jinbubyeo. Two types of $\mathrm{F}_{1}$ plants were obtained from the two cross combinations of Jinbubyeo-ABL1/Jinbubyeo-ABL2 and Jinbubyeo-ABL1/ Jinbubyeo-ABL3 (Fig. 2). These two $F_{1}$ plants were crossed to each other to pyramid the five resistance genes. Phenotypic selection and MAS were done from $F_{1}$ to $F_{5}$ to develop the five $R$ genes pyramided line (GPL). We selected the promising progenies in each segregating generation through simultaneous foreground and phenotypic selection to reduce linkage drag properties such as sterility, tallness, and late flowering, among others. The foreground and phenotypic selection reduced the population size for MAS. GPLs with linkage drag characteristics like sterility and transgressive phenotype could be eliminated, because the three Jinbubyeo-ABLs were recovered to the genetic background of the recurrent parent, Jinbubyeo (Suh et al. 2009, 2011, 2013). Validated markers were employed to ensure the integration and stacking of the five resistance genes (Fig. 3, 4). The best strategy to pyramid multiple genes in the shortest time is to transfer the genes simultaneously, generate a large backcross or self-pollinating population and employ foreground selection and flanking marker analysis to minimize possible linkage drag (Ye 2010; Rajpurohit et al. 2011; Suh et al. 2013). Finally, three GPLs were selected as promising lines with homozygous marker alleles for the five target $R$ genes: $X a 4+x a 5+X a 21$ to $\mathrm{BB}$, Pi40 to blast and Bph20 to BPH (Fig. 2, 4). The average percentage of donor parent chromosome substitution by SSR marker profiling in GPL1, GPL2 and GPL3 was 14.2, 12.6 and 14.2\%, respectively (Table 4, Fig. 6). The substituted chromosome segments in the GPLs were mainly distributed in the range of $19.7 \%$ to $54.1 \%$ around the target resistance genes on chromosomes 5, 6, 11 and 12 . Chromosomes 2, 3, 4, and 9 were completely converted to the Jinbubyeo genetic background with no introgressed chromosome segments from the donors (Fig. 6). However, chromosomes 7 and 8 contained donor chromosome segments ranging from $12.9 \%$ to $31.0 \%$. Because three near-isogenic lines of the Jinbubyeo genetic background for three kind of biotic stresses were used to pyramid the five target $R$ genes in this study, the three GPLs would contain higher introgressed donor chromosome segments than the three Jinbubyeo-ABLs. 
The three GPLs with five $R$ genes were evaluated by bioassay to determine their resistance against $\mathrm{BB}$, blast and BPH. Four Korean predominant races, K1, K2, K3 and K3a of $X o o$, were inoculated by the leaf clipping method. The GPLs pyramided with three $R$ genes, $X a 4+x a 5+X a 21$ were highly resistant against all isolates of $X o o$, with an average lesion length of $<0.3 \mathrm{~cm}$ (Table 3, Fig. 5). This result was consistent with the observation that the three gene combination pyramided lines expressed higher levels of resistance in comparison with the parental lines, as well as the two and single gene combinations (Singh et al. 2001; Joseph et al. 2004; Sundaram et al. 2008; Rajpurohit et al. 2011; Park et al. 2014; Pradhan et al. 2015). Also, the resistance level in the lines containing five $R$ genes for three biotic stresses was the same as the lines with only three $R$ genes $X a 4+x a 5+X a 21$ for BB (Suh et al. 2013). Especially, the three GPLs showed durable resistance to blast when the sequential planting method was employed. This result would be due to the relationship between a few $R$ genes, Piz, Pita and Pik, from the recurrent parent, Jinbubyeo (Cho et al. 2007) and Pi40, which shows broad-spectrum resistance (Suh et al. 2009). This means that synergistic action and/or quantitative complementation between the resistant genes might result in enhanced levels of resistance (Sanchez et al. 2000). The GPLs containing Bph18 were resistant to the insect pest, brown planthopper (Table 3, Fig. 5). During the development of $R$ gene-pyramided lines, although the lines were selected by foreground selection for phenotypic traits and MAS, the promising GPLs selected at the end showed resistance to brown planthopper. This result was consistent with the observation that the resistance levels of the pyramided lines for the resistance genes, Grh2 and Grh6, Grh4 and Grh6, and Grh5 and $q G R H 4$, to green rice leafhopper (Nephotettix cincticeps Uhler) demonstrated a gene pyramiding effect that significantly increased their resistance (Fujita et al. 2010). Also, the linkage drag was successfully overcome with the combination of phenotypic and marker-assisted selections. Our results suggest that all target genes for resistance to biotic and abiotic stress as well as major genes for important agronomic traits can be combined by foreground selection and MAS.

Yield and morpho-agronomic data for the three $R$ gene-pyramided lines revealed that the GPLs were similar to the recurrent parent for most features (Table 5). The DTH of the GPLs was 5-6 days longer than that of Jinbubyeo. The number of spikelets per panicle and the seed fertility of the GPLs were more than and lower than those of Jinbubyeo, respectively. The grain yield of GPL1 was significantly higher than that of Jinbubyeo. The higher yield of the pyramided lines may be due to the inheritance of some yield traits from the donor parent, in addition to the contributions of the recurrent parent Jinbubyeo to the pyramided line (Pradhan et al. 2015). Most characteristics related to grain quality like AC, PC, ADV of the three GPLs were recovered to the japonica recurrent parent Jinbubyeo, but the chalkiness of 0/2-1/2 for endosperm represented an increase from $0 / 1$ for the recurrent parent Jinbubyeo. This would mainly be attributed to unfavorable characteristics related to the grain quality traits from an indica donor, IR65482-7-216-1-2, for the brown planthopper resistance gene (Table 1, Jairin et al. 2009). GPL1, which had favorable agronomic traits similar to those of Jinbubyeo including grain yield, would be useful for enhancing the effective resistance for multiple biotic stresses and producing stable grain yield in japonica rice breeding programs.

\section{ACKNOWLEDGEMENTS}

This work was supported with the basic funds (Project No. PJ0113312015 and PJ0093252015) from the National Institute of Crop Science, Rural Development Administration, Republic of Korea.

\section{REFERENCES}

Cho YC, Kwon SW, Choi IS, Lee SK, Jeon JS, Oh MK, Roh JH, Hwang HG, Yang SJ, Kim YG. 2007. Identification of major blast resistance genes in Korean rice varieties (Oryza sativa L.) using molecular markers. J. Crop Sci. Biotech. 10: 265-276.

Divya B, Robin S, Rabindran R, Senthil S, Raveendran M, Joel AJ. 2014. Marker assisted backcrossing breeding approach to improve blast resistance in Indian rice (Oryza sativa) variety ADT43. Euphytica. 200:61-77. 
Frisch M, Melchinger AE. 2001. Marker-assisted backcrossing for simultaneous introgression of two genes. Crop Sci. 41: $1761-1725$

Fujita D, Yoshimura A, Yasui H. 2010. Development of nearisogenic lines and pyramided lines carrying resistance genes to green rice leafhopper (Nephotettix cincticeps Uhler) with the Taichung 65 genetic background in rice (Oryza sativa L.). Breeding Sci. 60: 18-27.

Han SS, Ryu JD, Shim HS, Lee SW, Hong YK, Cha KH. 2001. Breakdown of resistant cultivars by new race $\mathrm{KI}-1117 \mathrm{a}$ and race distribution of rice blast fungus during 1999 2000 in Korea. Res. Plant Dis. 7: 86-92 (in Korean, English summary).

IRRI (International Rice Research Institute). 1996. Standard evaluation system for rice. 4th ed. International Rice Research Institute, Manila, Philippines.

Jairin J, Teangdeerith S, Leelagud P, Kothcharerk J, Sansen K, Yi M, Vanavichit A, Toojinda T. 2009. Development of rice introgression lines with brown planthopper resistance and KDML105 grain quality characteristics through marker-assisted selection. Field Crop. Res. 110: 263-271.

Jena KK, Jeung JU, Lee JH, Choi HC, Brar DS. 2006. High-resolution mapping of a new brown planthopper $(\mathrm{BPH})$ resistance gene, Bph18(t) and marker-assisted selection for BPH resistance in rice (Oryza sativa L.). Theor. Appl. Genet. 112: 288-297.

Jena KK, Mackill DJ. 2008. Molecular markers and their use in marker-assisted selection in rice. Crop Sci. 48: 12661276.

Jeung JU, Heu SG, Shin MS, Vera Cruz CM, Jena KK. 2006. Dynamics of Xanthomonas oryzae pv. oryzae populations in Korea and their relationship to known bacterial blight resistance genes. Phytopathology 96: 867-875.

Jeung JU, Kim BR, Cho YC, Han SS, Moon HP, Lee YT, Jena KK. 2007. A novel gene, Pi40(t), linked to the DNA markers derived from NBS-LRR motifs confers broad spectrum of blast resistance in rice. Theor. Appl. Genet. 115: 1163-1177.

Joseph M, Gopalakrishnan S, Sharma RK, Singh VP, Singh AK, Singh NK, Mohapatra T. 2004. Combining bacterial blight resistance and basmati quality characteristics by phenotypic and molecular marker-assisted selection in rice. Mol. Breed. 13: 377-387.

Juliano BO. 1971. A simplified assay for milled rice amylose.
Cereal Sci. Today 16: 334-336.

Khush GS. 2005. What is will take to feed five billion rice consumers by 2030. Plant Mol. Biol. 59: 1-6.

Kim BR, Roh JH, Choi SH, Ahn SW, Han SS. 2004. Durability of rice cultivars to blast in Korean sequential planting method. Korean J. Breed. 36: 350-356.

Kim KY, Shin MS, Kim WJ, Mo YJ, Nam JK, Noh TH, Kim BK, Ko JK. 2009. Effective combination of resistance genes against rice bacterial blight pathogen. Korean J. Breed. Sci. 41: 244-251.

Leach JE, Davidson R, Liu B, Manosalva P, Mauleon R, Carrillo G, Bruce M, Stephens J, Diaz MG, Nelson R, Vera Cruz C, Leung H. 2007. Understanding broad-spectrum durable resistance in rice. Rice Genet. V: 191-207.

Lee EJ, Cho SY. 1990. Variation in races of rice blast disease and varietal resistance in Korea. Paper presented at the Focus on Irrigated Rice. Seoul, Korea. pp.27-31.

Lee JH, Lee JY, Yoon YN, Kim SY, Hur YJ, Yeo US, Sohn YB, Song YC, Park DS, Nam MH, Cho JH. 2015. Enhancement of panicle blast resistance in Korean rice cultivar 'Saeilmi' by marker assisted backcross breeding. Plant Breed. Biotech. 3: 1-10.

Lee KS, Rasabandith S, Angeles ER, Khush GS. 2003. Inheritance of resistance to bacterial blight in 21 cultivars of rice. Phytopathology 93: 147-152.

Little RR, Hilder GB, Dawson EH. 1998. Differential effect of dilute alkali on 25 varieties of milled white rice. Cereal Chem. 35: 111-126.

McCouch SR, Teytelman L, Xu Y, Lobos KB, Clare K, Walton M, Fu B, Maghirang R, Li Z, Xing Y, Zhang Q, Kono I, Yano M, Fjellstrom R, DeClerck G, Schneider D, Cartinhour S, Ware D, Stein L. 2002. Development and mapping of 2240 new SSR markers for rice (Oryza sativa L.). DAN. Res. 9: 199-207.

Murry MG, Thompson WF. 1980. Rapid isolation of high molecular-weight plant DNA. Nucleic. Acids. Res. 8: 4321-4325.

Neeraja CN, Maghirang-Rodriguez R, Pamploma A, Heuer S, Collard BCY, Septiningsih EM, Vergara G, Sanchez D, Xu K, Ismail AM, Mackill DJ. 2007. A marker-assisted backcross approach for developing submergence-tolerant rice cultivars. Theor. Appl. Genet. 115: 767-776.

Noh TH, Lee DK, Kang MH, Shin MS, Na SY. 2003. Identification of new race of Xanthomonas oryzae pv. oryzae (Xoo) in Korea. Phytopathology 93: S66. 
Noh TH, Lee DK, Park JC, Shim HK, Choi MY, Kang MH, Kim JD. 2007. Effect of bacterial leaf blight occurrence on rice yield and grain quality in different rice growth stage. Res. Plant. Dis. 13: 20-23.

Park HS, Kim KY, Kim WJ, Ko JC, Nam JK, Jeung JU, Kim BK, Lee JH. 2014. Development of breeding lines for early maturing glutinous japonica rice carrying bacterial blight resistance genes, Xa2, Xa3, xa5 and Xa21. Korean J. Breed. Sci. 46: 195-202 (Korean with English abstract). Pradhan SK, Nayak DK, Mohanty S, Behera L, Barik SR, Pandit E, Lenka S, Anandan A. 2015. Pyramiding of three bacterial blight resistance genes for broad-spectrum resistance in deepwater rice variety, Jalmagna. Rice 8: 19.

Rajpurohit D, Kumar R, Kumar M, Paul P, Awasthi AA, Basha PO, Puri A, Jhang T, Singh K, Dhaliwal HS. 2011. Pyramiding of two bacterial blight resistance and a semi dwarfing gene in Type 3 Basmati using marker-assisted selection. Euphytica 178: 111-126.

RDA (Rural Development Administration). 2003. Manual for standard evaluation method in agricultural experiment and research. Suwon, Korea. pp.838.

Sanchez AC, Brar DS, Huang N, Khush GS. 2000. Sequence tagged site markers-assisted selection for three bacterial blight resistance genes in rice. Crop Sci. 40: 792-797.

Shanti ML, Shenoy VV, Devi GL, Kumar VM, Premalatha P, Kumar GN, Shashidhar HE, Zehr UB, Freeman WH. 2010. Marker-assisted breeding for resistance to bacterial leaf blight in popular cultivars and parental lines of hybrid rice. J. Plant Pathol. 92: 495-501.

Singh S, Sidhu JS, Huang N, Vikal Y, Li Z, Brar DS, Dhaliwal HS, Khush GS. 2001. Pyramiding three bacterial blight resistance genes (xa5, xa13 and Xa21) using markerassisted selection into indica rice cultivar PR106. Theor. Appl. Genet. 102: 1011-1015.

Suh JP, Roh JH, Cho YC, Han SS, Kim YG, Jena KK. 2009.
The Pi40 gene for durable resistance to rice blast and molecular analysis of Pi40-advanced backcross breeding lines. Phytopathology 99: 243-250.

Suh JP, Yang SJ, Jeung JU, Pamplona A, Kim JJ, Lee JH, Hong HC, Yang CI, Kim YG, Jena KK. 2011. Development of elite breeding lines conferring Bph18 gene-derived resistance to brown planthopper $(\mathrm{BPH})$ by marker-assisted selection and genome-wide background analysis in japonica rice (Oryza sativa L.). Field Crop. Res. 120: 215-222.

Suh JP, Jeung JU, Noh TH, Cho YC, Park SH, Park HS, Shin MS, Kim CK, Jena KK. 2013. Development of breeding lines with three pyramided resistance genes that confer broad-spectrum bacterial blight resistance and their molecular analysis in rice. Rice 6: 5 .

Sundaram RM, Vishnupriya MR, Biradar SK, Laha GS, Reddy GA, Rani NS, Sarma NP, Sonti RV. 2008. Marker assisted introgression of bacterial blight resistance in Samba Mahsuri, an elite indica rice variety. Euphytica 160: 411-422.

Sundaram RM, Vishnupriya MR, Laha GS, Rani NS, Rao PS, Balachandran SM, Reddy GA, Sarma NP, Sonti RV. 2009. Introduction of bacterial blight resistance into Triguna, a high yielding, mid-early duration rice variety. Biotechnol. J. 4: 400-407.

Xi ZY, He FH, Zeng RZ, Zhang ZM, Ding XH, Li WT, Zhang GQ. 2006. Development of a wide population of chromosome single-segment substitution lines in the genetic background of an elite cultivar of rice (Oryza sativa L.). Genome 49: 476-484.

Xu Y, Crouch JH. 2008. Marker-assisted selection in plant breeding: from publication to practice. Crop Sci. 48: 391-407.

Ye G. 2010. Marker-assisted gene pyramiding for cultivar development. Plant Breed. Rev. 33: 219-256. 